\title{
KONSTRUKSI BUDAYA MUTU \\ RELEVANSINYA DENGAN MANAJEMEN MUTU GURU DALAM PEMBELAJARAN PENDIDIKAN AGAMA HINDU
}

\author{
Oleh \\ Ni Made Anggreni \\ Tenaga Pendidik pada Fakultas Dharma Acarya IHDN Denpasar
}

\begin{abstract}
Restoring the quality of the education cannot be separated from the role of the educators. The quality here refers to the attitudes, values, norms, and system that are shared within the institution to produce quality graduates. The educators are to create the conducive atmosphere at schools, which requires competence in class managemenet. The Hindu classes teach the students to be active in order to meet the standard quality of the education therefore reach the vision and fulfill mission of the institution.
\end{abstract}

Keywords: quality culture, quality management, teacher, Hindu education

\section{PENDAHULUAN}

Pendidikan merupakan suatu hal yang sangat penting dalam kehidupan, karena dengan pendidikan manusia akan bisa mengembangkan potensi yang dimilikinya. Akan tetapi pada kenyataannya pendidikan sering dilakukan hanya sebagai formalitas saja, dalam artian pendidikan itu berjalan sedemikian rupa tanpa memperhatikan mutu lulusan.Mutu lulusan dipengaruhi oleh mutu-mutu lainnya, seperti mutu guru, mutu management pengelola, mutu kurikulum, mutu sarpras dan lain-lain.Maka dari itu penting kiranya budaya mutu ini dikonstruksi oleh semua pihak yang terlibat dalam pendidikan.

\section{PEMBAHASAN}

Menurut Poerwadarminta menyatakan bahwa konstruksi berarti 1) cara membuat (menyusun) bangunan-bangunan (jembatan dan sebagainya), 2) susunan dan hubungan kata(1987:520). Mutu biasanya menggambarkan karakteristik langsung dari suatu produk atau jasa, seperti : kinerja (performance), kehandalan (reliability), mudah dalam penggunaan (easy of use), estetika (esthetics), dan lain sebagainya (Vincent Gaspersz,2001). ISO 8402 mendefinisikan mutu sebagai keseluruhan ciri dan karakteristik produk atau jasa yang kemampuannya dapat memuaskan kebutuhan, dan manajemen. Mutu sebagai semua aktivitas dari fungsi manajemen secara keseluruhan yang menentukan kebijakan mutu, tujuan-tujuan dan tanggung jawab, serta mengimplementasikannya melalui metode perencanaan mutu (Quality Planning), pengendalian mutu (Quality Control), jaminan mutu (Quality Assurance) dan peningkatan mutu (Quality Improvement).

Unsur-unsur utama dari standar adalah sistem mutu, kebijakan mutu dan manajemen mutu.Manajemen mutu meliputi penentuan dan pelaksanaan kebijakan mutu.Sistem mutu termasuk prosedur, proses, tanggung jawab, dan organisasi untuk melaksanakan manajemen 
mutu.Kebijakan mutu termasuk tujuan-tujuan organisasi dalam hal mutu.

Pada perusahaan, konstruksi budaya mutu merupakan suatu kegiatan yang harus dikembangkan untuk mendukung proses mutu atau mempertahankan sistem mutu yang ada perusahaan, demikian pula pada lembaga pendidikan. Mutu adalah penggerak dari manajemen berkualitas (Deming, 1986). Menurut Duran (1988) banyak defenisi dan maksud dari mutu, setiap orang mengartikan secara berlainan seperti kesesuaian dengan syarat/tuntutan, kesesuaian untuk pemakaian, perbaikan/penyempurnaan lanjutan, bebas dari kerusakan/kecacatan, melakukan segala sesuatu secara betul dari awal, sesuatu yang biasa untuk menyenangkan hati pelanggan. Oleh sebab itu mutu mempunyai banyak dimensi yang menggambarkan kebutuhan dan menyenangkan hati pelanggan.

Menurut Granross dalam Rita (2003) ada tiga pokok utama dalam mutu yaitu berkaitan dengan hasil, kesan, dan kreteria. Ketiga utama ini dikembangkan menjadi enam yaitu (i) professional danahli; (iii) sikap dan prilaku; (iii) akses dan fleksibel; (iv) dapat dipercayai dan amanah; (v) solusi yang tepat; dan (vi) reputasi.

Untuk pencapaian mutu yang baik, diperlukan kesadaran diri dari perusahaan untuk menjadikan mutu sebagai budaya dalam satu organisasi untuk setiap proses yang melibatkan seluruh anggotanya. Menurut Saraph dan Sabestian (1993), untuk menciptakan budaya mutu seluruh team dari perusahaan mempelajari mutu bersama-sama yang berkaitan dengan nilai-nilai sebagai pengembangan organisasi supaya mampu untuk terus hidup diluar lingkungannya dan juga untuk mengurus dirinya sendiri.

Menurut Soewarso (1999), budaya mutu adalah pola, nilai- nilai, keyakinan dan harapan anggota organisasi kepada pekerjaannya untuk menghasilkan produk dan perkhidmatan yang berkualitas. Sedangkan Goetch dan Davis (1994) menyatakan bahwa budaya ditunjukkan dalam kriteria-kriteria: prilaku sesuai semboyan, para pekerja dilibatkan dan dimotivasi, pekerjaan dilakukan dalam team, pemimpin dilibatkan, tanggungjawab kualitas secara bersama, sumberdaya yang mencukupi, pemimpin memberi contoh dan panduan, pendidikan dan latihan disediakan serta penghargaan diberikan.

Menurut Carlo, et.al. (2006) ada delapan faktor yang mempengaruhi budaya mutu dalam perusahaan jasa konstruksi di Indonesia. Kedelapan faktor tersebut terdiri dari struktur organisasi, kumunikasi, motivasi, kepemimpinan, kelompok kerja, sistem penghargaan, pendidikan dan latihan, dan pemberian kuasa.

Budaya mutu adalah prilaku, nilai-nilai dan norma-norma serta sistem yang dipahami bersama dalam suatu perusahaan dalam melaksanakan pekerjaan untuk menghasilkan pekerjaaN yang berkualitas. Hal ini dibangun melalui pengurus dengan delapan factor yaitu dimulai dengan struktur organisasi, kumunikasi, motivasi, kepemimpinan, kelompok kerja, sistem penghargaan, pendidikan danlatihan, dan pemberian kuasa. Kedelapan faKtor ini mempunyai kaitan dan mempengaruhi pembangunan budaya mutu. Melalui pelaksanaan yang baik dan sesuai dengan aturan yang berlaku pada perusahaan akan menghasilkan budaya mutu sesuai dengan visi, misi, dan tujuan organisasi. Bentuk budaya sangat komplek.

Dalam membentuk budaya organisasi, kepercayaaan dan nilai saling mendukung dan melengkapi satu sama lain. Agar dapat dimengerti dengan baik, budaya TQM (Total Quality Management) ini dibagi menjadi delapan elemen penting yaitu etika, integritas (kejujuran), kepercayaan, pelatihan (training), kerja tim (team work), kepemimpinan (leadership), penghargaan (recognition), dan komunikasi.

TQM telah diciptakan untuk menggambarkan sebuah filsafat yang menjadikan mutu sebagai tenaga penggerak di belakang 
kepemimpinan, desain, perencanaan, dan inisiatif perbaikan.Untuk hal itu, TQM membutuhkan bantuan dari kedelapan elemen kunci di atas.

Istilah manajemen berasal dari bahasa Inggris yaitu "manage" yang berarti mengelola, membina, mengendalikan, mengatur, menata ataupun menangani. Dibawah ini ada beberapa pendapat tentang arti dari manajemen sebagai berikut:

G.R. Terry (1960): "Management is the accomplishing of the predetermined, objective through the efforts of other people" (manajemen adalah melakukan pencapaian tujuan (organisasi) yang sudah ditentukan sebelumnya dengan mempergunakan bantuan orang lain). Harold Koontz dan Cyril O. Donnel (1959): "Management is getting done, through other people" (manajemen adalah penyelesaian pekerjaan melalui orang lain). John M.Pfifner(1967): “Management is concerned with the direction of these individuals and functions to achieve ends previously determined" (manajemen berhubungan dengan pengarahan orang dan tugas-tugasnya untuk mencapai tujuan yang telah ditetapkan).

Stoner dan Freeman (1992): Manajemen adalah proses perencanaan, pengorganisasian, pengarahan dan pengendalian upaya anggota organisasi dan proses penggunaan semua sumber daya organisasi untuk tercapainya tujuan yang telah ditetapkan.

Dengan demikian manajemen merupakan alat untuk mencapai tujuan yang diinginkan. Manajemen yang baik akan memudahkan terwujudnya tujuan organisasi atau perusahaan, karyawan dan masyarakat. Dengan manajemen, daya guna dan hasil guna unsurunsur (komponen) manajemen akan dapat ditingkatkan. Adapun unsur (komponen) manajemen terdiri dari man, money, methode, machines, materials dan market atau disingkat $6 \mathrm{M}$.
Lahirnya Undang-Undang No. 14 tahun 2005 tentang Guru dan Dosen dan Peraturan Pemerintah No. 19 Tahun 2005 tentang Standar Nasional Pendidikan, pada dasarnya merupakan kebijakan pemerintah yang didalamnya memuat usaha pemerintah untuk menata dan memperbaiki mutu guru di Indonesia.

Michael G. Fullan yang dikutip oleh Suyanto dan Djihad Hisyam (2000) mengemukakan bahwa "educational change depends on what teachers do and think...". Pendapat tersebut mengisyaratkan bahwa perubahan dan pembaharuan sistem pendidikan sangat bergantung pada "what teachers do and think". atau dengan kata lain bergantung pada penguasaan kompetensi guru.

Jika kita amati lebih jauh tentang realita kompetensi guru saat ini agaknya masih beragam. Sudarwan Danim (2002) mengungkapkan bahwa salah satu ciri krisis pendidikan di Indonesia adalah guru belum mampu menunjukkan kinerja (work performance) yang memadai. Hal ini menunjukkan bahwa kinerja guru belum sepenuhnya ditopang oleh derajat penguasaan kompetensi yang memadai, oleh karena itu perlu adanya upaya yang komprehensif guna meningkatkan kompetensi guru.

Peranan guru dalam sistem pendidikan nasional merupakan pusat aktivitas semua komponen pendidikan. Guru juga dipandang sebagai potensi yang memiliki nilai/guna ekonomi relatif lama. Produktivitas pendidikan banyak tergantung pada seberapa jauh kontribusi yang diberikan sumber daya ini melalui pelaksanaan tugas mereka sehari-hari. Dalam organisasi kependidikan, guru merupakan individu yang mempunyai peranan penting dalam menciptakan suasana yang kondusif untuk terciptanya proses belajar mengajar di sekolah. Untuk mencapai atau melaksanakan tugas dan pekerjaannya tersebut, guru harus mempunyai kemampuan 
yang memadai, yang perwujudannya akan nampak dalam kepuasan kerja, yang berimplikasi pada kinerja yang pada akhirnya berimplikasi pula pada kualitas hasil belajar.

Kepuasan kerja tidak lahir dengan sendirinya, akan tetapi dipengaruhi pula oleh bagaimana seorang kepala sekolah sebagi Top Leadersheep di sekolah, dalam kemampuan manajerialnya sebagai wahana dalam meramu seluruh tahapan manajemen di sekolah sejak proses perencanaan, pengorganisasian, pelaksanaan aktivitas organisai, sampai dengan proses pengawasan sebagai media umpan balik dalam mengevaluasi keseluruhan tahapan manajemen tersebut.

Kepuasan kerja guru tidak terlepas dari unsur-unsur di atas. Guru harus dapat menyelesaikan tugas-tugasnya dengan baik, dan bertanggungjawab atas hasil kerjanya. Kepuasan kerja guru inilah yang akhirnya akan melahirkan kualitas dari organisasi sekolah, dan pada gilirannya akan meningkatkan kinerja guru yang bersangkutan. Semakin kurat guru melaksanakan fungsinya, semakin terjamin tercipta dan terbinanya kesiapan dan keandalan seseorang sebagai manusia pembangunan. Dengan kata lain, potret dan wajah diri bangsa di masa depan tercermin dari potret diri para guru masa kini, dan gerak maju dinamika kehidupan bangsa berbanding lurus dengan citra guru ditengah-tengah masyarakat.

Kepuasan kerja pada dasarnya merupakan hal yang sangat individual. Oleh karena itu setiap individu akan memiliki tingkat kepuasan kerja yang berbeda-beda sesuai dengan system nilai yang berlaku pada dirinya. Semakin tinggi persepsi seseorang terhadap kegiatan yang sesuai dengan keinginannya, maka semakin tinggi pula tingkat kepuasan kerja yang akan dirsakannya.

Kepuasan kerja menurut Keith Davis dan Jhon W Newstrom (1977) adalah seperangkat perasaan pegawai tentang menyenangkan atau tidaknya pekerjaan mereka. Sementara pandangan Robin (1990) adalah sikap umum pekerja yang menilai perbedaan antara jumlah imbalan yang diterima dengan yang diyakininya seharusnya diterima.

Dari dua teori di atas dapat penulis simpulkan bahwa kepuasan kerja guru adalah perasaan emosional yang dimiliki oleh seorang guru berdasarkan pandangan yang menyenangkan untuk mewujudkan kenyataan sesuai dengan harapan yang diinginkannya. Dengan asumsi bahwa semakin tinggi terpenuhi sumber kepuasan kerjanya, maka semakin tinggi pula kepuasan kerjanya. Sebaliknya semakin tidak terpenuhinya sumber kepuasan kerja, maka semakin tidak puaslah guru yang bersangkutan.

Indikator sumber-sumber kepuasan kerja guru dalam tataran konteks ideal praktis, adalah:

a. Tingkat prestasi guru, dengan indikator keberhasilan guru dalam melaksanakan tugas, dalam memecahkan masalah, dan melihat hasil kegiatannya.

b. Tingkat pengakuan (penghargaan) yang diterima guru.

c. Tingkat tanggungjawab guru pada pekerjaannya.

d. Tingkat kesinambungan dan kepastian jenjang kepangkatan dan karier seorang guru.

Sementara itu, tingkat ketidak puasan kerja guru dapat timbul dari sumber-sumber berikut ini :

a. Tingkat kebijakan dan administrasi.

b. Tingkat pelaksanaan supervisi yang bersifat teknikal.

c. Tingkat kesejahteraan.

d. Tingkat hubungan antar personal.

e. Tingkat kondisi kerja.

f. Tingkat peluang untuk tumbuh.

g. Tingkat effek kerja terhadap kehidupan pribadi

h. Tingkat keamanan kerja.

i. Tingkat status.

Salah satu hal yang patut dipertimbangkan dalam upaya meningkatkan Kinerja 
Guru adalah melalui peningkatan fungsi komunikasi sesama guru maupun antara guru dengan siswa didiknya sehingga terjadi sebuah interaksi dan pertukaran informasi yang berguna seputar pengajaran dan pembelajaran yang mampu meningkatkan efektivitas kerja guru itu sendiri. Menurut Gary A. Davis dan Margaret A. Thomas (dalam Prof. Suyanto, Ph.D, artikel internet “Guru Yang Profesional Dan Efektif")., paling tidak ada empat kelompok besar ciri-ciri guru yang efektif. Keempat kelompok itu terdiri dari: Pertama, memiliki kemampuan yang terkait dengan iklim belajar di kelas, yang kemudian dapat dirinci lagi menjadi (a) memiliki kemampuan untuk menunjukkan empati, penghargaan kepada siswa, dan ketulusan; (b) memiliki hubungan baik dengan siswa; (c) mampu menerima, mengakui, dan memperhatikan siswa secara tulus; (d) menunjukkan minat dan antusias yang tinggi dalam mengajar; (e) mampu menciptakan atmosfir untuk tumbuhnya kerja sama dan kohesivitas dalam dan antar kelompok siswa; (f) mampu melibatkan siswa dalam mengorganisasikan dan merencanakan kegiatan pembelajaran; (g) mampu mendengarkan siswa dan menghargai hak siswa untuk berbicara dalam setiap diskusi; (h) mampu meminimal-kan friksi-friksi di kelas jika ada.

Kedua, kemampuan yang terkait dengan strategi manajemen pembelajaran, yang meliputi: (a) memiliki kemampuan untuk menghadapi dan menangani siswa yang tidak memiliki perhatian, suka menyela, mengalihkan pembicaraan, dan mampu memberikan transisi substansi bahan ajar dalam proses pembelajaran; (b) mampu bertanya atau memberikan tugas yang memerlukan tingkatan berpikir yang berbeda untuk semua siswa.

Ketiga, memiliki kemampuan yang terkait dengan pemberian umpan balik (feedback) dan penguatan (reinforcement), yang terdiri dari: (a) mampu memberikan umpan balik yang positif terhadap respon siswa; (b) mampu memberikan respon yang bersifat membantu terhadap siswa yang lamban belajar; (c) mampu memberikan tindak lanjut terhadap jawaban siswa yang kurang memuaskan; (d) Mampu memberikan bantuan profesional kepada siswa jika diperlukan.

Keempat, memiliki kemampuan yang terkait dengan peningkatan diri, terdiri dari: (a) mampu menerapkan kurikulum dan metode mengajar secara inovatif; (b) mampu memperluas dan menambah pengetahuan mengenai metode-metode pengajaran; (c) mampu memanfaatkan perencanaan guru secara kelompok untuk menciptakan dan mengembang-kan metode pengajaran yang relevan. Berdasarkan hal tersebut tersirat bahwa seorang guru harus mampu berkomunikasi dan mengkomunikasikan berbagai hal antara dirinya dengan siswa maupun unsur lainnya yang terlibat dalam proses pendidikan. Berdasarkan beberapa pemikiran di atas dapat diambil suatu kesimpulan bahwa kinerja guru sangat tergantung kepada kepuasan kerja guru dalam melaksanakan proses pembelajaran yaitu bagaimana guru merancang, melaksanakan dan mengevaluasi pembelajaran. Kepuasan guru dinilai penting untuk mendapatkan kenyamanan dalam bekerja, sehingga akan berimplikasi pada peningkatan kinerja guru. Terciptanya kerja pada seorang guru diharapkan terjadi peningkatan mutu pendidikan secara menyeluruh.

Pembangunan mutu dan kualitas pendidikan antara lain ditempuh melalui pembangunan mutu para pendidiknya, karena pendidikan merupakan "The man behind the system/program" serta sebagai faktor kunci yang turut menentukan keberhasilan pendidikan. Dalam hal ini Oteng Sutisna (1991:103) mengumukakan bahwa: Kualitas program pendidikan tidak hanya tergantung kepada konsep-konsep program yang cerdas tetapi juga pada personil pengajar yang 
mempunyai kesanggupan dan keinginan untuk berprestasi. Tanpa personil yang cakap dan efektif, program pendidikan yang dibangun di atas konsep-konsep yang cerdas serta dirancang dengn teliti pun tidak dapat berhasil.

Dengan pernyataan tersebut di lain pihak guru atau tenaga kependidikan lainnya harus memiliki rasa tanggunggjawab untuk meningkatkan kemampuan profesional sebagai pendidik, oleh karena itu tenaga kependidikan berkewajiban untuk berusaha mengembangkan profesionalnya sesuai dengan perkembangan tuntunan ilmu pengetahuan dan teknologi serta pembangunan bangsa.

Dalam upaya meningkatkan mutu pendidikan nasional, pemerintah khususnya melalui Depdiknas terus menerus berupaya melakukan berbagai perubahan dan pembaharuan sistem pendidikan kita. Salah satu upaya yang sudah dan sedang dilakukan, yaitu berkaitan dengan faktor guru. Lahirnya UndangUndang No. 14 tahun 2005 tentang Guru dan Dosen dan Peraturan Pemerintah No. 19 Tahun 2005 tentang Standar Nasional Pendidikan, pada dasarnya merupakan kebijakan pemerintah yang didalamnya memuat usaha pemerintah untuk menata dan memperbaiki mutu guru di Indonesia. Michael G Fullan yang dikutip oleh Suyanto dan Djihad Hisyam (2000) mengemukakan bahwa "educational change depends on what teachers do and think...". Pendapat tersebut mengisyaratkan bahwa perubahan dan pembaharuan sistem pendidikan sangat bergantung pada "what teachers do and think". atau dengan kata lain bergantung pada penguasaan kompetensi guru.

Jika kita amati lebih jauh tentang realita kompetensi guru saat ini agaknya masih beragam. Sudarwan Danim (2002) mengungkapkan bahwa salah satu ciri krisis pendidikan di Indonesia adalah guru belum mampu menunjukkan kinerja (work performance) yang memadai. Hal ini menunjukkan bahwa kinerja guru belum sepenuhnya ditopang oleh derajat penguasaan kompetensi yang memadai, oleh karena itu perlu adanya upaya yang komprehensif guna meningkatkan kompetensi guru.

Mengacu pada pengertian kompetensi di atas, maka dalam hal ini kompetensi guru dapat dimaknai sebagai gambaran tentang apa yang seyogyanya dapat dilakukan seseorang guru dalam melaksanakan pekerjaannya, baik berupa kegiatan, berperilaku maupun hasil yang dapat ditunjukkan. Lebih jauh, Raka Joni sebagaimana dikutip oleh Suyanto dan Djihad Hisyam (2000) mengemukakan tiga jenis kompetensi guru, yaitu :

(1) Kompetensi profesional; memiliki pengetahuan yang luas dari bidang studi yang diajarkannya, memilih dan menggunakan berbagai metode mengajar di dalam proses belajar mengajar yang diselenggarakannya.

(2) Kompetensi kemasyarakatan; mampu berkomunikasi, baik dengan siswa, sesama guru, maupun masyarakat luas.

(3) Kompetensi personal; yaitu memiliki kepribadian yang mantap dan patut diteladani. Dengan demikian, seorang guru akan mampu menjadi seorang pemimpin yang menjalankan peran: ing ngarso sung tulada, ing madya mangun karsa, tut wuri handayani.

Menurut Muhhibin Syah (1997:229), pengertian dasar kompetensi (competency) adalah kemampuan atau kecakapan. Padanan kata berasal dari bahasa inggris ini cukup banyak dan yang lebih relevan dengan pembahasan ini ialah kata proficiency dan ability yang memiliki arti kurang lebih sama yaitu kemampuan. Hanya proficiency lebih sering digunakan orang untuk menyatakan kemampuan berperingkat tinggi.

Disamping berarti kemampuan, kompetensi menurut Mc Leod (1989), yang dikutip oleh Muhibbin Syah (1997:229), dalam buku psikologi pendidikan berarti :"... the state 
of being legally competent or qualified, yakni keadaan yang berwewenang atau memenuhi syarat menurut ketentuan hukum."

Adapun kompetensi guru (teacher competency) menurut Barlow (1985) yang juga dikutip oleh Muhibbin Syah (1997 : 229), mengemukakan bahwa, kompetensi ialah "The ability of a teacher to responsibly perform his or her duties uppropriuty ". Artinya, kompetensi merupakan kemampuan seorang guru dalam melaksanakan kewajibankewajibannya secara bertanggung jawab dan layak.

Berdasarkan pengertian diatas, maka kompetensi guru dapat diartikan sebagai kemampuan dan kewenangan guru dalam menjalankan profesi keguruannya.Artinya guru yang piawai dalam melaksanakan profesinya dapat disebut sebagai guru yang kompeten dan profesional.Dari pengertian tersebut, dapat disimpulkan bahwa suatu pekerjaan yang bersifat profesional memerlukan beberapa bidang ilmu yang secara sengaja harus dipelajari dan kemudian dialpikasikan bagi kepentingan umum.Atas dasar pngertian ini, ternyata pekerjaan profesional berbeda dengan pekerjaan lainnya karena suatu profesi memerlukan kemampuan dan keahlian khusus dalam melaksanakan profesinya.Sebagaimana dikemukakan oleh Nana Sudjana, 1988, yang dikutip oleh Moh. Uzer Usman (1995 : 14), kata "Profesional berasal dari kata sifat yang berarti pencaharian dan sebagai kata benda yang berarti orang yang mempunyai keahlian seperti guru, dokter, hakim dan sebagainya".

Dengan kata lain pekerjaan yang bersifat profesional adalah pekerjaan yang hanya dapat dilakukan oleh mereka yang khusus dipersiapkan untuk itu dan bukan pekerjaan yang dilakukan oleh mereka yang karena tidak dapat memperoleh pekerjaan lain.

Bertitik tolak pada pengertian ini, maka pengertian guru profesional adalah orang yang memiliki kemampuan dan keahlian khusus dalam bidang keguruan sehingga ia mampu melaksanakan tugas dan fungsinya sebagai guru dengan kemampuan maksimal. Atau dengan kata lain, Guru profesional adalah orang yang terdidik dan terlatih dengan baik, serta memiliki pengalaman yang kaya dibidangnya. Yang dimaksud dengan terdidik dan terlatih bukan hanya memperoleh pendidikan formal tetapi juga harus menguasai berbagai strategi atau teknik dalam kegiatan belajar mengajar serta menguasai landasan-landasan kependidikan seperti yang tercantum dalam kompetensi guru yang akan diuraikan berikut.

Selanjutnya dalam melakukan kewenangan profesionalnya, guru dituntut memiliki seperangkat kemampuan (competenev) yang beraneka ragam.Lebih lanjut, Muhhibin Syah (1992:230) dalam buku psikologi pendidikan menjelaskan bahwa, "dalam menjalankan kewenangan profesionalnya, yang dituntut memiliki keanekaragaman kecakapan (competencies) yang bersifat psikologis, yang meliputi: kompetensi kognitif, kompetensi afektif guru, dan kompetensi psikomotor guru".

Pembangunan mutu dan kualitas pendidikan antara lain ditempuh melalui pembangunan mutu para pendidiknya, karena pendidikan merupakan "The man behind the system/program" serta sebagai faktor kunci yang turut menentukan keberhasilan pendidikan. Dalam hal ini Oteng Sutisna (1991:103) mengumukakan bahwa: Kualitas program pendidikan tidak hanya tergantung kepada konsep-konsep program yang cerdas tetapi juga pada personil pengajar yang mempunyai kesanggupan dan keinginan untuk berprestasi. Tanpa personil yang cakap dan efektif, program pendidikan yang dibangun di atas konsep-konsep yang cerdas serta dirancang dengn teliti pun tidak dapat berhasil.

Dengan pernyataan tersebut di lain pihak guru atau tenaga kependidikan lainnya harus memiliki rasa tanggunggjawab untuk meningkatkan kemampuan profesional sebagai pendidik, oleh karena itu tenaga kependidikan 
berkewajiban untuk berusaha mengembangkan profesionalnya sesuai dengan perkembangan tuntunan ilmu pengetahuan dan teknologi serta pembangunan bangsa.

Kaitannya dengan profesionalisme tenaga pendidik/pengajar, Fakry Gaffar (1987:159), menyebutkan bahwa "Kinerja guru terbagi kedalam tiga bidang besar, yaitu : (1) content knwledge, (2) behavioral skills, (3) huan relatios skill'.

Dalam hal ini pertama, Content knowledge berkaitan dengan penguasaan materi pengetahuan yang akan dijarkan kepada peserta didik. Kedua, mengenai Behavioral skills, berupa keterampilan perilaku yang harus dimiliki oleh pengajar/pendidik yang berkaitan dengan penguasaan didaktis metodologis pengajar arah apakah pendidikan yang bersifat pedagogis untuk pendidik anak pun andragogis untuk pendidikan orang dewasa. Ketiga, human relations skill, adalah kemampuan manusiawi untuk dapat menjalin hubungan yang baik dengan unsur manusia yang terlibat dalam proses pendidikan yakni peserta didik, pengajar, dan pimpinan lembaga pendidikan.

Kinerja guru dalam organisasi pendidikan selalu menjadi pembicaraan masyarakat ramai yang harus mendapatkan perhatian. Kinerja guru tidak boleh diabaikan untuk mengacu prestasi belajar siswa yang menjadi idaman masyarakat. Adapun indikator yang dapat diperhatikan untuk mendapatkan kinerja guru yang baik adalah dengan adanya kemampuan guru dalam: (a) membuat perangkat pembelajaran; (b) melaksanakan kegiatan pembelajaran; (c) memberikan dorongan belajar kepada murid dan (d) memahami dan mengikuti pengembangan kurikulum.

Seorang guru dalam melaksanakan tugasnya tidak hanya mengajar atau menyajikan materi pelajaran di depan kelas, tetapi juga harus memahmi tugas-tugas lainnya. Hadri Nawawi (1985:124) mengemukakan bahwa "kompetensi guru itu berkenaan dengan kemampuan dasar teknis edukatif dan administratif yaitu: (a) penguasaan bahan pengajaran, (b) mengelola program belajar mengajar, (c) mengelola kelas, (d) menggunakan media/sumber, (e) mengelola dan menyempurnakan interaksi belajar mengajar, (f) memahami fungsi dan program layanan bimbingan belajar.

Sementara itu Sanusi (1995:45) mengemukakan tiga aspek utama kemampuan yang dimiliki oleh seorang guru, yakni: (a) rencana pelajaran (teaching plans and mateials); (b) prosedur mengajar (classroom procedure); dan (c) hubungan antar pibadi (interpersonal skills).

Senada dengan Sanusi, Charles K. Johnsons (1974:6) mengemukakan beberapa kompetensi yang harus dimiliki guru, yaitu: komponen kinerja (performance component), komponen bahan pengajaran (the teaching subject component), komponen proses pengajaran (the taugh process component), komponen penyesuaian pribadi (the peronal adjustment component) dan komponen sikap (the attitude component).

Sedangkan Conners seperti dikutip Hasibuan (1996:54) melihat kegiatan dari sisi tugas guru, Conners mengidentifikasi tugas mengajar guru menjadi tiga tahap, yaitu: (a) tahap sebelum mengajar, (b) tahap pengajaran, dan (c) tahap sesudah mengajar.

Sedangkan Ratchs, sebagaimana dikutif Djam' an Satori (1980 : 36) mengemukakan tiga belas fungsi yng diharpkan dimiliki oleh seorang guru, yaitu:

a. Berinisiatif, membimbing dan memberi arah,

b. Mengubah dan menyempurnakan kurikulum,

c. Memberitahukan, menerangkan dan menunjukkan bagaimana caranya,

d. Melaksanakan dengan membangkitkan rasa aman dan terjamin,

e. Proses penjelasan, dari anggapan sampai kepada pembuktian, 
f. Mengkoordinir kerja kelompok,

g. Membantu memperkaya masyarakat,

h. Meneliti dan memperbaiki pekerjaan,

$i$. "Evluating, recording dan reporting,

j. "School-wde function",

k. Memelihara keindahan kelas,

1. Memelihara dan meningkatkan karier profesional

m. Hidup sebagai warga negara yang baik.

Peraturan Mentri Agama tentang pengelolaan pendidikan agama pada sekolah dalam Bab I pasal 1 ayat 1 yaitu Pendidikan agama adalah pendidikan yang memberikan pengetahuan dan membentuk sikap, kepribadian, dan keterampilan peserta didik dalam mengamalkan ajaran agamanya, yang dilaksanakan sekurang-kurangnya melalui mata pelajaran pada semua jalur, jenjang dan jenis pendidikan.

Kemudian pada Bab I pasal 1 ayat 7 yaitu Guru Pendidikan Agama adalah pendidik professional dengan tugas utama mendidik, mengajar, membimbing, mengarahkan, melatih, memberi teladan, menilai dan mengevaluasi peserta didik.

Teknik Peningkatan Mutu Gurudalam hal ini peran guru sebagai pendidik merupakan peran yang berkaitan dengan tugas-tugas memberikan bantuan dan dorongan, tugastugas pengawasan dan pembinaan serta tugastugas yang berkaitan dengan mendisiplinkan anak agar anak menjadi patuh terhadap orang tua, patuh dengan guru di sekolah, aturanaturan sekolah dan norma hidup dalam keluarga dan masyarakat. Peran guru sebagai model atau contoh bagi anak. Setiap anak mengharapkan guru mereka dapat menjadi contoh atau model pembelajaran baginya.

\section{SIMPULAN}

Konstruksi budaya mutu merupakan suatu kegiatan yang harus dikembangkan untuk mendukung proses mutu atau mempertahankan sistem mutu yang ada pada lembaga pendidikan.Peranan guru dalam sistem pendidikan nasional merupakan pusat aktivitas semua komponen pendidikan. Guru juga dipandang sebagai potensi yang memiliki nilai/ guna ekonomi relatif lama. Guru harus mampu mengelola kelas dalam proses pembelajaran demi tercapainya tujuan pembelajaran khususnya pembelajaran agama Hindu.

\section{DAFTAR PUSTAKA}

http://binapersadaindonesia.blogspot.com/ 2012/09/manajemen-mutu-guru.html (Diakses pada tanggal: 25 Maret 2015, jam: 14.08 Wita)

http://pendis.kemenag.go.id/file/dokumen/ KMA162010.pdf(Diakses pada tanggal: 25 Maret 2015, jam: 14.22 Wita)

http://ilhamakbar1.blogspot.com/2012/02/ penerapan-standar-iso-9000-padabidang.html (Diakses pada tanggal: 25 Maret 2015, jam: 14.38 Wita)

http://www.epublication.fab.utm.my/178/1/ ICCI2006S1PP11.pdf(Diakses pada tanggal: 25 Maret 2015, jam: 14.48 Wita)

http://bali.kemenag.go.id/ index.php?a=berita\&id=201553 (Diakses pada tanggal: 13 April 2015, jam: 15.02 Wita)

https://dnoeng.wordpress.com/2010/06/15/ delapan-elemen-budaya-mutu/ (Diakses pada tanggal: 13 April 2015, jam: 16.08 Wita)

Poerwadarminta, W.J.S. 1987. Kamus Umum Bahasa Indonesia.Jakarta: Balai Pustaka. 